\title{
Kontribusi Cultural Values Terhadap Kecenderungan Residivisme Pada Narapidana Di Lembaga Pemasyarakatan Kelas Iia Jember
}

\author{
Panca Kursistin Handayani \\ Fakultas Psikologi, Universitas Muhammadiyah Jember \\ pikaha_ocha@unmuhjember.ac.id \\ Novita Sylvia Ulva \\ Fakultas Psikologi, Universitas Muhammadiyah Jember \\ silviaulva@gmail.com \\ Eva Fahmadia Jilan Maulida \\ Fakultas Psikologi, Universitas Muhammadiyah Jember \\ evajilanmaulida96@gmail.com
}

\begin{abstract}
Research on recidivism tendencies which is influenced by internal factors that have been carried out is related to psychological problems (2014), self-regulation (2016) and self-control (2017). Based on this research it appears that there is a missing link related to the source of initial encouragement that comes from within the individual as a process of interaction and internalization of the initial experiences of individuals with parents, ancestors and other significant people. Related to this, this study aims to determine the effect of Cultural Value on the Trend of Recidivism in Jember Class IIA Prisoners.

This type of research is associative quantitative that is to determine the relationship between one variable with another variable and the effect of a variable on other variables. There are two psychological scales used in this study, the Cultural Values scale adapted from The Potrait Value Questionnaire (PVQ$R R$ ) compiled by Schwartz and the Residivism Tendency scale adapted from the Psychopathy Check List-Revised (PCL-R) compiled by Hare. The results of this study are expected to be input/reference in developing community values-based community intervention programs.

The results showed a calculated $F$ value of 0.471 with a significance level of $0.493>0.05$, which means that there was no influence of Cultural Value on the Trend of Residivism. Descriptive test shows that as many as 107 prisoners (56\%) have high cultural values and 84 inmates (44\%) have low cultural values. This means that prisoners tend to use cultural values as a reference in behavior, but they do not necessarily have compliance with the values that exist in the community. The highest percentage is the value of Universalism, Achievement, and Security. While the lowest percentage is the value of Stimulation, Benevolence Care, and Self Direction.
\end{abstract}


Keywords: cultural value; recidivism; prisoners

\begin{abstract}
ABSTRAK
Penelitian mengenai kecenderungan residivisme yang dipengaruhi oleh factor internal yang sudah pernah dilakukan adalah berkaitan dengan problem-problem psikologis (2014), regulasi diri (2016) dan kontrol diri (2017). Berdasarkan penelitian tersebut tampak bahwa ada rantai yang hilang (missing link) terkait sumber dorongan awal yang berasal dari dalam diri individu sebagai proses interaksi dan internalisasi pengalaman-pengalaman awal individu dengan orangtua, leluhur dan significant person yang lain. Terkait hal itu, penelitian ini bertujuan untuk mengetahui pengaruh Cultural Value terhadap Kecenderungan Residivisme pada narapidana Lapas Kelas IIA Jember.

Jenis penelitian ini adalah kuantitatif asosiatif yaitu untuk mengetahui hubungan antara satu variabel dengan variabel yang lainnya dan pengaruh suatu variabel terhadap variabel lain. Ada dua skala psikologi yang digunakan dalam penelitian ini yaitu skala Cultural Values yang diadaptasi dari The Potrait Value Questionnaire (PVQ-RR) yang disusun oleh Schwartz dan skala Kecenderungan Residivisme yang diadaptasi dari Psychopathy Check List-Revised (PCL-R) yang disusun oleh Hare. Hasil penelitian ini diharapkan dapat menjadi masukan/rujukan dalam menyusun program intervensi komunitas berbasis nilai-nilai budaya.

Hasil penelitian menunjukkan nilai $\mathrm{F}$ hitung 0,471 dengan tingkat signifikansi $0,493>0,05$ yang berarti tidak ada pengaruh Cultural Value terhadap Kecenderungan Residivisme Narapidana. Uji deskriptif menunjukkan bahwa sebanyak 107 narapidana (56\%) memiliki nilai-nilai budaya yang tinggi dan 84 narapidana $(44 \%)$ memiliki nilai-nilai budaya yang rendah. Artinya bahwa narapidana cenderung menggunakan nilai-nilai budaya sebagai rujukan dalam berperilaku, namun belum tentu memiliki kepatuhan terhadap nilai-nilai yang ada dimasyarakat. Prosentase tertinggi berada pada nilai Universalism, Achievement, dan Security. Sedangkan prosentase terendah berada pada nilai Stimulation, Benevolence Care, dan Self Direction.
\end{abstract}

Kata Kunci: cultural value; residivisme; narapidana

\title{
Pendahuluan
}

Fenomena residivisme atau tindak kejahatan berulang masih menjadi tantangan dan problem besar dalam upaya pembinaan dan penanggulangan kejahatan di berbagai Lembaga Pemasyarakatan. Berdasarkan KUHP (dalam Azriadi, 2011) narapidana dikatakan residivis jika: 1) Narapidana tersebut pernah melakukan kesalahan berupa tindakan kriminal atau kejahatan dan menjadi narapidana di Lembaga Pemasyarakatan. 2) Dalam waktu kurang dari 5 tahun ia 
melakukan kesalahan serupa sehingga menyebabkan ia masuk dan ditahan kembali di sebuah Lembaga Pemasyarakatan. Batasan residivisme di Indonesia tersebut juga sejalan dengan batasan yang berlaku di negara lain. Bartol dan Bartol (dalam Kristianingsih, 2016) mendefinisikan residivisme sebagai kembalinya seseorang ke tindak kriminal (biasanya diukur dengan penangkapan) setelah dinyatakan bersalah melakukan pidana.

Bila dicermati insidensi tindak pidana berulang (recidivism) di berbagai lembaga pemasyarakatan di Indonesia semakin meningkat akhir-akhir ini, terutama untuk kasus narkoba, curanmor, terorisme, dan penipuan. Penelitian Jones (2014), menemukan bahwa tingkat recidivism pada narapidana kasus teorisme cukup tinggi, dari 29 narapidana yang telah dibebaskan, 23 orang kembali melakukan tindak pidana serupa selama 6 tahun terakhir. Tanpa program rehabilitasi yang efektif dan kondisi lapas yang overkapasitas yaitu mencapai lebih dari 65\% (1 sel lebih dari 30 orang), maka recividism akan menjadi problem yang sangat mungkin terjadi. Berdasarkan data jumlah narapidana Lapas Kelas IIA Jember tahun 2016, jumlah residivis terakhir adalah kurang lebih 100 orang dengan perincian sebagai berikut 21 orang untuk kasus 363, 15 orang untuk kasus 196, dan kasus 303-362-114 masing-masing sebanyak 10 orang. Jumlah terbesar adalah untuk kasus pencurian, penipuan, dan narkoba (Handayani, 2016).

Banyak faktor yang mempengaruhi insidensi tindak pidana berulang tersebut, baik yang berasal dari individu sendiri maupun faktor lingkungan. Hasil penelitian ini dari Nugraha dan Abidin (2013) menemukan bahwa residivis digerakkan oleh factor internal meliputi kontrol diri lemah, ketagihan, habbit/kebiasaan, niat, keahlian/skill serta gaya hidup. Sedangkan faktor eksternal meliputi kondisi lingkungan/environment, adanya pengaruh orang lain, dan adanya faktor ekonomi. Senada dengan temuan sebelumnya, Permatasari (2016) juga menemukan beberapa factor yang menyebabkan terjadinya kejahatan berulang yaitu pengalaman yang kurang menyenangkan, pendidikan yang rendah, pergaulan yang salah, kehidupan hedonis, lingkungan yang kurang sehat, kebutuhan hidup, dan labelling/stereotype yang diberikan masyarakat pada pelaku. 
Sementara Maxmen (1986) menemukan bahwa terdapat factor sosiokultur yang kemudian membentuk nilai-nilai budaya dalam diri individu yang mempengaruhi pilihan-pilihan tindakan dan perilaku individu secara umum. Secara umum, cultural values (nilai-nilai budaya) didefinisikan sebagai sebuah hasil atau penerapan budaya dalam kehidupan. Schwartz (2006) mendefinisikan cultural values (nilainilai budaya) berangkat dari konsep tentang budaya. Schwartz (2006) memandang budaya sebagai kompleks makna, keyakinan, praktik, simbol, norma, dan nilainilai yang lazim di antara orang-orang dalam masyarakat. Nilai yang berlaku ditekankan dalam masyarakat mungkin merupakan ciri paling sentral dari budaya. Nilai-nilai ini menekankan konsep bersama tentang apa yang baik dan diinginkan dalam budaya, atau cita-cita budaya. Nilai budaya menekankan bentuk dan membenarkan keyakinan individu, kelompok, tindakan, dan tujuan. Pengaturan dan kebijakan kelembagaan, norma, dan praktik sehari-hari mengungkapkan penekanan nilai budaya yang mendasar dalam masyarakat.

Berdasarkan hasil wawancara awal (FGD) dengan narapidana di Lapas Kelas IIA Jember yang dilakukan, terungkap bahwa beberapa narapidana menyatakan bahwa mereka sangat percaya pada keyakinan-keyakinan yang dipelajarinya dari orangtua dan leluhur mereka. Beberapa mitos, kepercayaan dan keyakinan akan suatu hal yang turun temurun dikenalkan oleh leluhur terkait kebaikan, kejujuran, kekuasaan, keamanan, tradisi dan lain-lain menjadi rujukan mereka untuk bertindak. Misalnya, ketika menceritakan mengenai rasa bersalah akan kejahatan yang telah dilakukannya, mereka menyatakan bahwa perasaan bersalah itu muncul ketika mengingat ajaran tentang kebaikan terhadap orang lain yang sudah mereka langgar. Hal ini menunjukkan bahwa sebenarnya nilai kebaikan masih menjadi rujukan tindakan mereka. Sementara pernyataan yang berbeda juga muncul dari hasil wawancara. Beberapa narapidana mengatakan bahwa mereka tahu ketika menipu orang lain artinya mereka telah melawan nilai kejujuran yang telah diajarkan sejak kecil, namun sebagian besar mereka tidak merasa melakukan ketidakjujuran karena banyak juga yang melakukan hal yang sama tapi tidak ketahuan. Hal ini menunjukkan bahwa yang menjadi rujukan utama bukanlah nilai kejujuran tetapi apa yang berlaku umum di masyarakat. 
Terkait dorongan pribadi, ada sebagian narapidana yang mengatakan bahwa sebenarnya perilaku mereka tersebut sebagai bentuk keinginan untuk dominan dan memiliki kekuatan/kelebihan dari orang lain karena sebelumnya mereka selalu merasa diremehkan dan disepelekan. Menurut mereka, biarlah orang menyebut mereka jahat, yang penting orang lain hormat, takut, dan mengganggap mereka kuat. Kekuatan dan kekuasaan menurut mereka adalah sumber keberhasilan dalam hidup.

Bila mencermati hasil FGD diatas, tampak bahwa sebenarnya perilaku narapidana tersebut banyak dipengaruhi oleh keyakinan, kepercayaan, dan pandangan-pandangan yang diajarkan turun temurun oleh leluhur mereka. Hal-hal tersebut seringkali menjadi rujukan, pedoman, dan pertimbangan dalam pilihan tindakan-tindakannya dalam menyelesaikan masalah dengan orang lain. Konsep inilah yang secara teoritis kita sebut dengan nilai-nilai yang bersumber dari budaya yang diturunkan dari generasi ke generasi. Disadari atau tidak, perilaku baik ataupun buruk yang dilakukan individu terdorong oleh sumber nilai yang sudah terinternalisasi sejak kecil.

Individu yang meyakini adanya nilai kebaikan sebagai sumber panduan hidupnya, maka akan cenderung terdorong untuk melakukan tindakan sesuai dengan prinsip kebaikan tersebut, dan akan cenderung menghindar dari segala hal yang melanggar nilai tersebut. Demikian pula, bagi individu meletakkan nilai kekuatan dan kekuasaan sebagai hal yang penting, maka akan cenderung melakukan segala cara dan tindakan untuk mewujudkan nilai-nilai tersebut meskipun dengan melanggar hak orang lain atau menyakiti orang lain. Ketika nilai-nilai yang diyakininya sejalan dengan norma-norma dan hukum yang berlaku di masyarakat, maka individu akan terhindar dari konsekuensi jeratan hukum akibat tindakannya. Sebaliknya ketika nilai-nilai yang diyakininya tidak bersesuaian dengan norma-norma, maka dengan hukuman sekalipun tidak akan membuat individu menjadi terhindar dari tindakan criminal.

Peneliti tertarik mengeksplorasi fenomena nilai-nilai budaya dalam kaitannya dengan pembentukan kecenderungan tindak kejahatan berulang, berpijak pada asumsi bahwa peran dari nilai-nilai budaya terhadap pembentukan 
perilaku adalah sebagai dasar pembentukan perilaku yang paling awal. Menurut Koentjaraningrat (Supsiloani, 2008), nilai-nilai budaya terdiri dari konsepsikonsepsi yang hidup dalam alam pikiran sebagian besar warga masyarakat mengenai hal-hal yang mereka anggap mulia. Sistem nilai yang ada dalam suatu masyarakat dijadikan orientasi dan rujukan dalam bertindak. Oleh karena itu, nilai budaya yang dimiliki seseorang mempengaruhinya dalam menentukan alternatif, cara-cara, alat-alat, dan tujuan-tujuan. Zitoune dan Gillespie (2015) menyatakan bahwa Value (nilai-nilai) budaya yang terinternalisasi pada diri individu akan membentuk pemikiran (minds). Prosesnya dapat diuraikan sebagai berikut: awalnya nilai-nilai budaya tersebut mendorong sebuah pemahaman terhadap suatu pengalaman, dan interpretasi terhadap pengalaman tersebut membentuk pemikiran (minds) terkait suatu situasi yang dihadapi. Kemudian pemikiran akan situasi ini akan berpengaruh terhadap pilihan tindakan berikutnya. Berdasarkan asumsi teoritis tersebut, dapat disimpulkan bahwa individu yang mempunyai value (nilainilai) sebagai rujukan perilakunya akan menempatkan nilai-nilai budaya sebagai bahan pertimbangan dalam bertindak.

Penelitian mengenai kecenderungan residivisme (tindak kejahatan berulang) pada narapidana di Lapas Kelas IIA Jember sudah pernah dilakukan sebelumnya, baik yang terkait factor internal maupun eksternal. Kecenderungan residivisme yang dipengaruhi oleh factor internal yang sudah pernah dilakukan adalah berkaitan dengan problem-problem psikologis (Handayani, 2014), regulasi diri (Handayani, 2017) dan kontrol diri (Maulida, 2017). Sementara penelitian sebelumnya mengenai factor eksternal yang ditemukan memberikan kontribusi dalam pembentukan kecenderungan residivisme adalah peran pemenjaraan yang justru memberi efek pembelajaran untuk munculnya tindak kejahatan berulang yang disebut dengan fenomena school of crimes (Handayani, 2016). Dari beberapa penelitian sebelumnya tersebut tampak bahwa ada rantai yang hilang (missing link) terkait sumber dorongan awal yang berasal dari dalam diri individu sebagai proses interaksi dan internalisasi pengalaman-pengalaman awal individu dengan orangtua, leluhur dan significant person yang lain. Hasil penelitian ini diharapkan dapat memberikan jawaban terkait hal ini. 


\section{Metode}

Jenis penelitian ini adalah penelitian kuantitatif dengan bentuk asosiatif yaitu suatu bentuk penelitian yang dirancang dengan maksud untuk mengetahui hubungan antara satu variabel dengan variabel yang lainnya dan bagaimana suatu variabel mempengaruhi variabel lain (Sugiyono, 2010).

Populasi dalam penelitian ini adalah narapidana sebanyak 422 orang berikut adalah karakteristik dari subjek :

a. Narapidana pria dan wanita Lapas Klas II A Jember.

b. Narapidana yang bisa membaca dan menulis

Pengambilan sampel menggunakan tabel isaac dan Michael dengan taraf kesalahan 5\% (Sugiyono, 2012), sehingga sampel yang digunakan sebanyak 191 orang.

Teknik pengumpulan sampel dalam penelitian ini menggunakan teknik Insidental Sampling, yaitu teknik penentuan sampel berdasarkan kebetulan atau insidental bertemu dengan peneliti dapat digunakan sebagai sampel, bila dipandang orang yang kebetulan ditemui itu cocok sebagai sumber data (Sugiyono, 2001).

Pengumpulan data dalam penelitian ini adalah dengan menggunakan skala psikologi. Ada 2 (dua) skala psikologi yang digunakan dalam penelitian ini yaitu skala Cultural Values dan skala Kecenderungan Residivisme.

\section{Skala Cultural Values}

Alat ukur yang digunakan untuk mengukur Cultural Values (nilai-nilai budaya) adalah alat ukur yang diadaptasi dari The Potrait Value Questionnaire (PVQ-RR) yang disusun oleh Schwartz pada tahun 2012. Bentuk skala yang digunakan adalah skala likert, terdiri dari 5 (lima) pilihan jawaban yaitu: tidak seperti saya sama sekali; tidak seperti saya; sedikit seperti saya; cukup seperti saya; dan sangat mirip dengan saya.

Alat ukur yang digunakan untuk mengukur Cultural Values (nilai-nilai budaya) ini mengungkap 19 nilai dasar yang ada pada setiap individu yaitu self direction thought, self direction action, stimulation, hedonism, achievement, 
power dominance, power resources, face, security personal, security societal, tradition, conformity rules, conformity interpersonal, humility, universalism nature, universalism concern, universalism tolerance, benevolence care, dan benevolence dependability.

Penyusunan alat ukur ini untuk lebih jelasnya dijabarkan dalam bentuk blueprint pada tabel skala Cultural Values sebagai berikut:

Tabel 1. Blue Print Skala Cultural Values

\begin{tabular}{clcc}
\hline No & \multicolumn{1}{c}{ Dimensi } & Nomor Item & Jumlah Item \\
\hline 1 & Self-direction Thought & $1,23,39$ & 3 \\
\hline 2 & Self-direction Action & $16,30,56$ & 3 \\
\hline 3 & Stimulation & $10,28,43$ & 3 \\
\hline 4 & Hedonism & $3,36,46$ & 3 \\
\hline 5 & Achievement & $17,32,48$ & 3 \\
\hline 6 & Power Dominance & $6,29,41$ & 3 \\
\hline 7 & Power Resources & $12,20,44$ & 3 \\
\hline 8 & Face & $9,24,49$ & 3 \\
\hline 9 & Security Personal & $13,26,53$ & 3 \\
\hline 10 & Security Societal & $2,35,50$ & 3 \\
\hline 11 & Tradition & $18,33,40$ & 3 \\
\hline 12 & Conformity Rules & $15,31,42$ & 3 \\
\hline 13 & Conformity Interpersonal & $4,22,51$ & 3 \\
\hline 14 & Humility & $7,38,54$ & 3 \\
\hline 15 & Universalism Nature & $8,21,45$ & 3 \\
\hline 16 & Universalism Concern & $5,37,52$ & 3 \\
\hline 17 & Universalism Tolerance & $14,34,57$ & 3 \\
\hline 18 & Benevolence Care & $11,25,47$ & 57 \\
\hline 19 & Benevolence Dependability & $19,27,55$ & 3 \\
\hline & & Jumlah & 3 \\
\hline & & & 3 \\
\hline
\end{tabular}

\section{Skala}

\section{a) Kecenderungan Residivisme (Tindak Kejahatan Berulang)}

Alat ukur yang digunakan untuk mengukur kecenderungan Residivisme (tindak kejahatan berulang) adalah alat ukur yang diadaptasi dari Psychopathy Check List-Revised (PCL-R) yang disusun oleh Hare (dalam Sari, 2015). Psychopathy Checklist-Revised (PCL-R) digunakan untuk memprediksi kecenderungan residivisme dengan kekerasan dan tanpa kekerasan. Hare dalam Sari (2015) mengatakan bahwa, Psychopathy Checklist dan Psychopathy Checklist-Revised (PCL-R) dapat memprediksi dengan baik potensi kekerasan 
dan residivis secara kuat. Banyak penelitian yang mengindikasi bahwa PCL dan PCL-R dapat memprediksikan residivis dengan kekerasan maupun tidak di masa depan pada populasi pelaku kejahatan.

Psychopathy Checklist Revised (PCL-R) merupakan checklist yang terdiri dari 20 item, dimana setiap aitemnya memiliki skor 0 sampai 2. Skor 0 dalam tiap item berarti tidak ada indikasi sampai maksimal skor 2 yang berarti memiliki indikasi psikopat berbasis pada wawancara yang luas dan rangkuman data secara institusional. Nilai yang didapat dari PCL-R ialah 0 sampai 40 dengan skor 30 atau lebih merupakan indikasi psikopat dan skor 20 atau kurang merupakan indikasi bukan psikopat. Berikut blueprint Psychopathy Checklist Revised (PCLR) untuk mengukur residivis berdasarkan teori yang dikembangkan oleh Hare (1970).

Tabel 2. Blueprint Skala Psychopathy Checklist Revised (PCL-R)

\begin{tabular}{|c|c|c|c|}
\hline No & $\begin{array}{c}\text { Aspek } \\
\text { Residivisme }\end{array}$ & Indikator & $\begin{array}{l}\text { No. } \\
\text { Aitem }\end{array}$ \\
\hline \multirow{4}{*}{1} & \multirow{4}{*}{ Interpersonal } & Kurang menarik perhatian & 1 \\
\hline & & Nilai harga diri yang berlebihan & 2 \\
\hline & & Kebohongan patologi & 3 \\
\hline & & Kelicikan & 4 \\
\hline \multirow{4}{*}{2} & \multirow{4}{*}{ Afektif } & Tidak merasa bersalah & 5 \\
\hline & & Tidak mudah dipengaruhi & 6 \\
\hline & & Kurang empati & 7 \\
\hline & & $\begin{array}{l}\text { Gagal menerima tanggung jawab untuk } \\
\text { melakukan aksi }\end{array}$ & 8 \\
\hline \multirow{5}{*}{3} & \multirow{5}{*}{ Gaya hidup } & Butuh stimulasi & 9 \\
\hline & & Gaya hidup parasit & 10 \\
\hline & & Rendah akan tujuan realistis jangka panjang & 11 \\
\hline & & Impulsif & 12 \\
\hline & & Tidak bertanggung jawab & 13 \\
\hline \multirow{5}{*}{4} & \multirow{5}{*}{ Antisosial } & Tidak terkontrol & 14 \\
\hline & & Masalah pada masa lalu & 15 \\
\hline & & Kenakalan remaja & 16 \\
\hline & & Pembebasan bersyarat & 17 \\
\hline & & Pandai dalam berbagai pembuatan kriminal & 18 \\
\hline \multirow{3}{*}{5} & \multirow{3}{*}{$\begin{array}{c}\text { Perilaku } \\
\text { seksual }\end{array}$} & Dorongan perilaku seks terkontrol & 19 \\
\hline & & Ketidaksetiaan & 20 \\
\hline & & Jumlah & \\
\hline
\end{tabular}

Sumber : Hare (Sari, 2015) 
Pengambilan data dibagi dalam dua sesi, yang dilaksankan pada tanggal 27 dan 28 Juni 2019. Dua sesi pengambilan data tersebut dilakukan di hari yang berbeda dan jam yang berbeda menyesuaikan dengan jadwal yang diberikan oleh pihak Lapas. Pelaksanaa pengambilan data dengan cara memberikan angket kepada subyek yang sudah berkumpul di Aula yang dibentuk menjadi beberapa kelompok yang mana satu kelompok terdapat maksimal 10 orang narapidana. Kemudian dijelaskan oleh peneliti untuk cara pengisiannya, namun dalam hal ini ada beberapa subyek yang tidak bisa membaca dan menulis sehingga peneliti membantu untuk pengisian angket. Hambatan dalam proses pengambilan data adalah untuk menemukan subjek penelitian yang sesuai kriteria populasi, karena meskipun beberapa narapidana tercatat mempunyai tingkat pendidikan SMP keatas, namun pada saat pengambilan data ternyata ada beberapa yang membacanya belum lancar. Hal ini disebabakan karena banyak narapidana yang putus sekolah atau sehari-hari jarang terpapar kegiatan membaca dan kegiatan akademik lainnya. Untuk mengatasi hal tersebut, tim peneliti membantu subjek penelitian untuk menjawab pertanyaan dalam kuisioner dengan cara memandu dan membacakan setiap item pertanyaan, serta memberikan penjelasan bila ada kalimat yang tidak mereka pahami.

\section{Hasil Dan Pembahasan}

Hasil penelitian menunjukkan nilai $\mathrm{F}$ hitung 0,471 dengan tingkat signifikansi 0,493 > 0,05 yang berarti bahwa tidak terdapat pengaruh Cultural Value terhadap Kecenderungan Residivisme narapidana di Lapas Kelas IIA Jember.

Tabel 3. Uji Hipotesis

\begin{tabular}{|c|c|c|c|c|c|c|}
\hline Model & & Sum of Squares & df & Mean Square & $\mathbf{F}$ & Sig. \\
\hline \multirow[t]{3}{*}{1} & Regression & 621.538 & 1 & 621.538 & .471 & $.493^{\mathrm{a}}$ \\
\hline & Residual & 249253.226 & 189 & 1318.800 & & \\
\hline & Total & 249874.764 & 190 & & & \\
\hline
\end{tabular}

a. Predictors: (Constant), Kecenderungan Residivis

b. Dependent Variable: Nilai-nilai Budaya 
Sumbangan efektif pengaruhnya adalah sebesar 0,002 yang dilihat dari nilai $\mathrm{R}$ Square sehingga dapat diinterpretasikan bahwa pengaruh variable $\mathrm{X}$ sebesar 0,2\% terhadap variabel Y dan 99,8\% lainnya dipengaruhi oleh faktor-faktor lain diluar variabel $\mathrm{X}$.

Hasil penelitian yang menunjukkan bahwa tidak ada pengaruh Cultural Value terhadap kecenderungan Residivisme pada narapidana Lapas Kelas IIA Jember tidak membuktikan argumentasi teoritis bahwa nilai-nilai budaya otomatis akan menjadi sumber rujukan dalam berperilaku. Tampaknya ada sebuah mata rantai yang mengantarai manifestasi nilai (value) tersebut sehingga mewujud menjadi perilaku. Penelitian Zitoune dan Gillespie (2015) sebelumnya menyatakan bahwa Value (nilai-nilai) budaya yang terinternalisasi pada diri individu akan membentuk pemikiran (minds). Prosesnya dapat diuraikan sebagai berikut: awalnya nilai-nilai budaya tersebut mendorong sebuah pemahaman terhadap suatu pengalaman, dan interpretasi terhadap pengalaman tersebut membentuk pemikiran (minds) terkait suatu situasi yang dihadapi. Kemudian pemikiran akan situasi ini akan berpengaruh terhadap pilihan tindakan berikutnya. Berdasarkan asumsi teoritis tersebut, dapat disimpulkan bahwa individu yang mempunyai value (nilai-nilai) sebagai rujukan perilakunya akan menempatkan nilai-nilai budaya sebagai bahan pertimbangan dalam bertindak, namun asumsi teoritis tersebut tampaknya masih dapat dijelaskan dalam beberapa perpektif.

Bila ditinjau secara definitive, menurut Tjahjono H (dalam Rahayuningsih, 2013) value (nilai-nilai) terdiri dari personal value dan social value. Personal value adalah semacam reaksi pribadi (subjective reaction) terhadap lingkungan sekitar dan dunia sekeliling kita. Personal value ini berkembang pada masa awal kehidupan atau masa kanak-kanak sebagai hasil interaksi dan pengalaman individu dengan orang-orang yang berpengaruh dalam kehidupannya, terutama orangtua. Personal value bersifat intrinsic, berasal dari diri sendiri, jadi bukan merupakan standart eksternal yang diterapkan terhadap diri sendiri. Menurut Harisson (dalam Rahayuningsih, 2013), nilai pribadi mempengaruhi persepsi terhadap situasi dan problem, mempengaruhi keseluruhan proses dalam memilih, mempengaruhi hubungan interpersonal, dan mempengaruhi penerimaan atau 
penolakan terhadap tekanan dari luar dirinya termasuk tuntutan dan norma/aturan yang berkembang di masyarakat sekitar. Sementara Social Value adalah merupakan system nilai yang berkembang melalui kesepakatan di masyarakat berupa seperangkat norma, aturan, kebiasaan, dan keyakinan bersama yang terbentuk dari hasil interaksi antar individu dalam masyarakat. Jika personal value hanya berdampak pada individu, bersifat self centered atau berdampak tidak langsung terhadap orang lain, sebaliknya Social value ini mempunyai dampak yang penting bagi orang-orang disekitar individu. Dalam konteks ini, hasil penelitian yang menyatakan tidak adanya pengaruh nilai-nilai budaya terhadap kecenderungan kejahatan berulang tampaknya dapat diterangkan dengan menggunakan kajian mengenai personal value dan social value ini. Masingmasing narapidana membawa personal value tersendiri sebelum mereka masuk Lapas. Personal value yang dibawa narapidana dari luar lapas kemudian berasimilasi dengan social value yang ada didalam Lapas. Jika personal value yang mereka bawa dari luar Lapas sejalan dengan social value yang terbentuk dalam Lapas maka perilaku mereka akan sangat dipengaruhi oleh value/nilai-nilai yang dianutnya. Sebaliknya, jika ternyata personal value narapidana tidak sejalan dengan social value dalam Lapas, maka akan terjadi tarik menarik pengaruh sesuai kebutuhan situasi saat itu, terutama terkait penyesuaian diri dan survival needs didalam Lapas. Menurut Pritikin (2009), ketika didalam penjara narapidana belajar dari teman-temannya yang lebih dulu masuk mengenai bagaimana melakukan kejahatan dan menghindari deteksi kejahatan dengan lebih efektif. Ia juga menegaskan bahwa narapidana tidak hanya belajar mengenai teknik-teknik kriminalitas pada sesama narapidana, tetapi juga menginternalisasi norma-norma subkultur antisosial didalam lapas. Sehingga dapat dikatakan bahwa sebenarnya proses sosialisasi dan adaptasi antar narapidana tidak hanya melibatkan proses modelling terkait sikap, karakter dan tindakan, namun juga terjadi internalisasi nilai (value), norma-norma, kebiasaan dan subkultur yang mengarah pada perilaku berisiko kejahatan. Kekerasan, saling manipulasi, dan transaksi kepentingan menjadi nilai-nilai dan norma penyelesaian masalah yang menggejala sehari-hari dan dipelajari sebagai cara efektif untuk mencapai tujuan. Semakin lama 
seseorang tinggal didalam Lapas, maka semakin sering dirinya terpapar dengan hal tersebut, sehingga semakin kuat nilai-nilai dan norma itu terinternalisasi, dan pada akhirnya nanti nilai-nilai dan norma itulah yang akan menjadi rujukan utama dalam kehidupannya bahkan setelah bebas/keluar lapas.

Menurut Zigami, O'Connor, Blanchard dan Edenburn (dalam Rahayuningsih, 2013), value (nilai-nilai) dapat dibedakan menjadi means (tata cara, proses) dan ends (tujuan akhir, goals). Keberhasilan dalam hidup, kebahagiaan dan kesejahteraan adalah sebagian contoh dari ends value, sementara jujur, adil, kerja keras, dan persaingan adalah sebagian dari contoh means value. Dalam Rokeach's Value Survei (dalam Yuwono dkk, dalam Rahayuningsih, 2013), ends value disebut dengan nilai terminal yaitu nilai yang merujuk pada keadaan akhir eksistensi yang diinginkan oleh manusia, sementara means value sejalan dengan konsep nilai instrumental yang merujuk pada cara-cara yang ditempuh untuk mencapai nilai terminal tersebut. Secara umum bisa jadi ends value setiap narapidana adalah sama dengan kebanyakan orang pada umumnya yaitu keberhasilan dan kebahagiaan dalam hidup, namun means value mereka bisa jadi berkembang tidak sejalan dengan social value yang berkembang di masyarakat yang lebih menekankan pada cara-cara yang sesuai dengan norma, tidak melanggar hak orang lain, atau tidak menyakiti orang lain. Kajian mengenai tidak kongruen atau sejalannya antara ends value dan social means value yang berkembang pada diri narapidana bisa menjadi argumentasi lain terkait temuan penelitian yang menyatakan bahwa value tidak berpengaruh terhadap kemunculan perilaku atau value hanya memberikan kontribusi yang sangat kecil dalam pembentukan perilaku individu.

Sementara itu, hasil uji deskriptif menunjukkan bahwa dari 191 narapidana di Lapas Klas II A Jember sebanyak 107 narapidana memiliki kategori nilai-nilai budaya yang tinggi dengan prosentase $56 \%$ dan 84 narapidana memiliki kategori nilai-nilai budaya yang rendah dengan prosentase $44 \%$. Hal ini menunjukkan bahwa narapidana sebagai subjek penelitian cenderung menggunakan nilai-nilai budaya sebagai rujukan dalam berperilaku, cenderung memiliki kepatuhan terhadap nilai-nilai yang ada dimasyarakat, sehingga ketika seseorang akan 
melakukan sesuatu ia akan melihat nilai-nilai budaya yang ada dilingkungan sekitarnya.

Tabel 4. Kategori Tingkatan Cultural Value

\begin{tabular}{lrrrr}
\hline & & & & \multicolumn{2}{c}{ Cumulative } \\
& Frequency & Percent & Valid Percent & Percent \\
\hline Nilai budaya tinggi & 107 & 56.0 & 56.0 & 56.0 \\
\hline Nilai budaya rendah & 84 & 44.0 & 44.0 & 44.0 \\
\hline Total & 191 & 100.0 & 100.0 & \\
\hline
\end{tabular}

Bila ditinjau dari aspek-aspek nilai budaya, maka kategori skor Nilai-nilai budaya ditemukan sebagai berikut:

Tabel 5. Urutan Kategori Nilai-nilai Budaya

\begin{tabular}{|c|c|c|c|}
\hline Kategori & $\begin{array}{c}\text { No } \\
\text { Urut }\end{array}$ & Nilai-Nilai Budaya & Prosentase $(\%)$ \\
\hline \multirow{4}{*}{ Tinggi } & 1 & Universalism nature & $71,7 \%$ \\
\hline & 2 & Universalism tolerance & $66 \%$ \\
\hline & 3 & Achievement & $62,8 \%$ \\
\hline & 4 & Security Personal & $61,3 \%$ \\
\hline \multirow{3}{*}{ Rendah } & 1 & Stimulation & $60,2 \%$ \\
\hline & 2 & Benevolence Care & $58,6 \%$ \\
\hline & 3 & Self Direction Thought & $51,3 \%$ \\
\hline
\end{tabular}

Hasil diatas menunjukkan bahwa subjek penelitian menjadikan nilai Universalism Nature, Universalism Tolerance, Achievement, dan Security Personal sebagai nilai tertinggi yang mendasari perilakunya. Hal ini menunjukkan bahwa narapidana yang menjadi subjek penelitian menempatkan keempat nilai tersebut sebagai nilai terpenting yang menjadi rujukan tingkah laku sehari-hari. Meskipun telah dijelaskan sebelumnya bahwa nilai tidak selalu langsung termanifestasi dalam perilaku namun sebagian besar dorongan bersumber pada nilai-nilai tersebut. Menurut Swartz (dalam Fitriah, 2014), nilai Universalism Nature yang tinggi artinya subjek cenderung melindungi lingkungan, persatuan dengan alam, keindahan dunia. Nilai Universalism Tolerance yang tinggi mengindikasikan wawasan atau toleran yang luas, kebijaksanaan atau pemahaman matang, mendengarkan orang yang berbeda atau memahami mereka yang tidak setuju. Secara khusus perilaku yang terkait dengan dominasi nilai Universalisme Nature ini tidak dapat diobservasi dan mewujud dalam perilaku sehari-hari 
narapidana di dalam Lapas, hal ini tentunya terkait kehidupan di lapas yang kurang memfasilitasi manifestasi dari perilaku ini. Namun dapat dijelaskan bahwa nilai Universalism Tolerance tampak dalam kecenderungan perilaku narapidana yang sangat mudah beradaptasi dengan perbedaan, mudah menerima keberadaan orang lain secara apa adanya, berusaha memahami latar belakang tindak kejahatan masing-masing tanpa banyak menghakimi, dan cenderung mau mendengarkan sudut pandang yang berbeda mengenai perilakunya terutama bila hal tersebut disampaikan oleh pemegang otoritas (kalapas, petugas lapas, dokter, atau pemuka agama yang datang ke Lapas). Meskipun insidensi keributan dan pertengkaran antar narapidana di Lapas kerap terjadi, namun hal tersebut jarang dipicu oleh adanya perbedaan personal, lebih dikarenakan konflik antar kepentingan kelompok.

Sementara itu, narapidana yang menjadi subjek penelitian juga ditemukan memiliki nilai Achievement yang tinggi artinya mereka akan cenderung mengejar kesuksesan personal dengan menunjukkan kompetensinya berdasarkan standar budaya atau kultur, untuk menghasilkan persetujuan sosial atau penerimaan sosial (Swartz, dalam Fitriah, 2014). Hal ini dapat dijelaskan dari dinamika interaksi narapidana selama didalam maupun sebelum masuk lapas. Hasil wawancara dengan narapidana mengungkapkan bahwa sebagian besar dari mereka menyatakan bahwa tindak pidana yang dilakukannya awalnya bersumber dari upaya mereka untuk menunjukkan pada keluarga dan orang-orang sekitarnya bahwa mereka mempunyai kemampuan untuk menjadi orang yang berhasil. Tekanan dari lingkungan yang tinggi kerapkali membuat mereka ingin segera membuktikan keberhasilan tanpa melalui proses panjang, sehingga dipilihlah jalan keluar untuk berhasil yang cenderung berisiko yang akhirnya mengirim mereka menjadi penghuni lapas. Sedangkan ketika di Lapas, dorongan untuk mempertahankan harga diri di mata sesama narapidana juga kerap muncul, yang bersumber dari keinginan untuk tampak lebih kompeten dari yang lain. Penelitian Handayani (2016) menunjukkan bahwa ada kecenderungan narapidana untuk berbagi ilmu kejahatan didalam lapas dengan salah satu tujuannya adalah mendapatkan pengakuan dari sesama narapidana bahwa mereka lebih canggih 
dalam melakukan teknik/trik kejahatan. Hal ini dilakukan untuk menunjukkan kompetensi yang melebihi teman narapidana yang lain, yang membuat mereka akan menjadi rujukan untuk bertanya, mempunyai pengaruh dalam interaksi sesama narapidana, lebih dihormati dan ditakuti. Disisi lain, ada juga beberapa narapidana yang menunjukkan kompetensinya dengan cara yang lebih positif, dengan cara menampilkan potensi dirinya selama di lapas dalam bentuk perubahan perilaku positif maupun prestasi-prestasi dan kompetensi khusus (hafalan Alqur'an, bidang seni dan keolahragaan, bidang kerohanian, computer, keadministrasian dan lain-lain), yang kemudian membuat mereka diberikan kesempatan oleh Lapas untuk berperan sebagai tamping, kepala kamar, dan tugas penting lain didalam Lapas. Fenomena ini sebenarnya merupakan hal yang bersifat kompetitif antar narapidana meskipun tidak ada aturan secara tertulis, namun semua pihak menyadari bahwa dengan menunjukkan kemampuan/kompetensi yang lebih diantara teman narapidana yang lain akan membuka jalan bagi kesempatan mendapatkan kemudahan, fasilitas, pengurangan hukuman, bahkan mendapatkan rekomendasi dari lapas yang bermanfaat setelah mereka keluar lapas.

Berikutnya, nilai-nilai budaya yang juga mendominasi adalah Security Personal dan Security Value. Menurut Swartz (dalam Fitriah, 2014), individu yang memiliki nilai Security Personal yang tinggi artinya ia mempunyai perhatian utama atau sehari-hari seperti kebersihan maupun perhatian yang lebih besar seperti keamanan dirinya, sementara Security value dapat muncul dalam perilaku menghindar dari perkelahian, menghindar dari rasa sakit, menghindari konflik, bertindak sesuai dengan aturan/norma yang berlaku. Hasil penelitian ini menggambarkan bahwa subjek penelitian menempatkan kebutuhan akan rasa aman baik secara personal maupun terkait sumber nilai rasa amannya sebagai rujukan perilakunya.

Sebaliknya, hasil penelitian menemukan skor yang rendah pada nilai Stimulation, Benevolence Care dan Self Direction Thought. Nilai Stimulation yang rendah menunjukkan bahwa individu kurang menyukai kegembiraan, kebaruan dan tantangan. Hasil wawancara mengungkapkan bahwa sebagian narapidana 
menganggap kegembiraan bahkan menjadi sebuah barang mewah yang jarang terlintas dalam pikiran mereka yang sehari-hari bergelut dengan kesulitan hidup dan permasalahan. Selain itu, kebaruan dan tantangan dianggap memberikan risiko yang lebih besar dan tidak memberikan keuntungan bagi hidup mereka yang sudah sulit.

Subjek penelitian juga ditemukan mempunyai nilai Benevolence Care yang rendah, artinya subjek kurang mempunyai keinginan untuk membantu atau bekerja untuk kesejahteraan orang lain, kurang jujur atau kurang tulus, kurang bisa memaafkan atau bersedia mengampuni. Bila dianalisis lebih jauh, sebenarnya nasib mereka menjadi narapidana yang menghabiskan sebagian hidupnya sebagai manusia hukuman sebagian besar bersumber dari kurangnya kepedulian pada kepentingan pihak lain, dan keberpihakan yang nyata terhadap kepentingan dirinya sendiri tanpa memperhatikan hak-hak orang lain. Berdasarkan hasil wawancara, bahkan sebagian dari mereka mengatakan bahwa sebenarnya yang mereka lakukan bukanlah sebuah kejahatan, tidak banyak narapidana yang menyatakan pertobatan dan penyesalan diri atas perbuatan kriminalnya. Sebagian besar memandang perbuatan kriminal mereka dari sudut pandang kerugian dirinya, dan sangat sulit memunculkan pemahaman bahwa ada korban yang sangat dirugikan atas perbuatan mereka. Ada yang menyatakan bahwa hal itu adalah akibat nasib sial mereka sehingga tertangkap, ada yang mengatakan bahwa itu adalah akibat ulah pihak lain yang tidak menyukai mereka, dan bahkan ada pula yang menyatakan keinginan untuk membalas dendam kepada pihak-pihak yang membuatnya dipenjara setelah mereka bebas nanti (Handayani, 2016).

Selain itu, nilai Self Direction Thought dari subjek juga menunjukkan kategori rendah, artinya subjek kurang memiliki otonomi pemikiran, kurang kreativitas atau imajinasi, daya ingin tahu rendah, dan kurang mempunyai ide atau kreasi baru. Sebagian besar narapidana berasal dari individu yang kurang kompeten dalam melakukan coping dan problem solving pada saat menghadapi permasalahan hidup, mereka cenderung kurang mempunyai referensi terkait penyelesaian masalah yang sesuai dengan situasi dan kondisi saat itu. Narapidana lebih banyak memilih cara-cara lama dan kurang berani mencoba hal-hal baru 
dalam penyelesaian masalah terutama bila terkait konflik atau masalah perekonomian. Hasil ini memperkuat penelitian sebelumnya tentang fenomena School of Crimes dalam kasus residivisme di Lapas (Handayani, 2016) yang menunjukkan bahwa sebagian narapidana menganggap Lapas sebagai tempat belajar banyak hal dari sesama napi, bahkan inspirasi mengenai strategi kejahatan dapat mereka pelajari dari sesama napi, bukan dari hasil pemikiran mereka sendiri. Narapidana juga mengakui mempunyai karakteristik yang mudah terpengaruh orang lain dan tidak mempunyai kemandirian terutama ketika berada dalam kondisi penuh masalah dan tekanan (stress). Kecenderungan untuk mengulang kejahatan sebelum 5 tahun masa pembebasan juga sangat dipengaruhi oleh rigiditas berpikir dan kurangnya kemampuan dalam mengelola ide dalam pemecahan masalah.

\section{Kesimpulan Dan Saran}

\section{Kesimpulan}

Hasil penelitian menunjukkan beberapa kesimpulan sebagai berikut:

1. Tidak ada pengaruh Cultural Value terhadap Kecenderungan Residivisme pada Narapidana Lapas Kelas IIA Jember

2. Tingkatan Cultural Value pada narapidana Lapas Kelas IIA Jember berada pada kategori TINGGI. Nilai-nilai budaya yang berada pada kategori tinggi adalah nilai Universalisme Nature, Universalisme Tolerance, Achievement, dan Security Personal. Sedangkan nilai-nilai budaya yang berada pada kategori rendah adalah Stimulation, Benevolence Care, dan Self Direction Thought.

\section{Saran}

\section{Bagi Lembaga Pemasyarakatan}

Berdasarkan hasil penelitian yang menunjukkan bahwa narapidana cenderung menggunakan nilai-nilai budaya sebagai rujukan dan pedoman dalam berperilaku, maka disarankan kepada pihak Lapas untuk memanfaatkan potensi terkait nilai-nilai, kepercayaan, adat kebiasaan yang diyakini narapidana sebagai dasar untuk melakukan pendekatan, 
pembinaan, penanganan masalah perilaku di Lapas serta pengembangan diri narapidana. Intervensi berbasis nilai-nilai budaya akan lebih mudah diterima dan berdampak pada perubahan perilaku secara signifikan karena berasal dari hal-hal yang tidak jauh dari kehidupan mereka sehari-hari. Secara khusus ditemukan bahwa nilai-nilai yang paling berpengaruh dalam kehidupan narapidana adalah Universalism, Achievement dan Security, disarankan kepada pihak Lapas untuk membuat program intervensi atau pembinaan dengan berbasis nilai-nilai tersebut.

\section{Bagi Peneliti Selanjutnya}

a. Hasil penelitian menemukan bahwa nilai-nilai budaya masih menjadi rujukan narapidana dalam berperilaku namun sumbangannya sangat kecil, diasumsikan ada intervening variable atau variable moderator yang mengantarai hubungan atau pengaruh antara kedua variable, sehingga disarankan pada peneliti selanjutnya untuk menemukan variable-variabel yang berperan dalam manifestasi nilai kedalam perilaku.

b. Hasil penelitian ini berhasil membuat profil nilai-nilai budaya yang mempengaruhi perilaku narapidana, namun belum dapat menggambarkan dinamika bekerjanya nilai-nilai tersebut dalam mempengaruhi perilaku. Disarankan kepada peneliti selanjutnya untuk mengekspolorasi hal tersebut baik dengan menggunakan pendekatan kualitatif maupun kuantitatif.

\section{DAFTAR PUSTAKA}

Azriadi. (2011). Pelaksanaan Pembinaan Narapidana Residivis berdasarkan Prinsip Pemasyarakatan di Lembaga Pemasyarakatan Kelas IIA Biaro. Artikel Ilmiah. Program Pasca Sarjana Ilmu Hukum. Universitas Andalas Padang.

Fitriah, E.A. (2014). Personal values dan internal political efficacy terhadap partisipasi politik mahasiswa pemilih pemula. Psympathic, Jurnal Ilmiah Psikologi. Volume 1, Nomer 2, Halaman 244-254. 
Handayani, P.K. (2015). Makna Hukuman dalam Perspektif Narapidana. Tinjauan Psikologis dan Agama. Prosiding Seminar Nasional \& Call for Paper Agama dan Budaya. Fakultas Psikologi Universitas Muhammadiyah Jember. Vol 1, Juli 2016.

(2016). Fenomena School of Crimes pada Narapidana Tindak Kejahatan Berulang di Lapas Kelas IIA Jember. Laporan Penelitian Internal Universitas Muhammadiyah Jember. Tidak Diterbitkan.

- (2017). Gambaran Regulasi Diri Narapidana Residivis di Lembaga Pemasyarakatan Kelas IIA Jember. Laporan Penelitian Internal Universitas Muhammadiyah Jember. Tidak diterbitkan.

Kristianingsih, S.A. (2016). Residivisme Narapidana Narkoba Dari Perspektif Kognitif sosial Bandura. Surabaya.

Kunz, C., dan Pedersen, L. (2010). Psychopathy as a Risk Factor for Violent Recidivism: Investigating the Psychopathy Checklist Screening Version (PCL:SV) and the Comprehensive Assessment of Psychopathic Personality (CAPP) in a Forensic Psychiatric Setting. Denmark.

Maxfield, D.L., dan Hare, M. (2004). The Criminal History Computation Of The Federal Sentencing Guideline. U.S.

Maulida, E.F.J. (2017). Pengaruh Kontrol Diri terhadap Kecenderungan Residivisme Narapidana di Lembaga Pemasyarakatan Kelas IIA Jember. Skripsi. Tidak diterbitkan.

Nugraha, I.D., Abidin, Z. (2013). Motivasi Kejahatan repetitif di Lembaga Pemasyarakatan Pati.

Permatasari, O.C.D. (2016). Studi Fenomenologi Pengalaman Narapidana Kategori Residivis. Skripsi: Fakultas Psikologi Universitas Sanata Dharma Jogjakarta.

Pritikin, M.H. (2009). Is Prison Inreasing Crime?. Wisconsin Law Review. Vol 1, Mei 2009, hal 1054-1059.

Rahayuningsih, I. (2013). Peranan personal value pemimpin dalam pembuatan keputusan organisasi. Jurnal Psikosains. Vol 6, Nomor 1, Agustus 2013.

Sari, L.L. (2015). Pengaruh Harapan Terhadap Kecenderungan Residivis Pada Narapidana Di Lapas Klas I Malang. Malang: Universitas Islam Negri Malang. 
Schwartz, SH. (2004). Mapping and Interpreting Cultural Differences around the World. The Hebrew University of Jerusalem. . (2006). A Theory of Cultural Value Orientation: Explication and Application. Leiden: Koninklijke Brill NV. Comparative Sociology, Vol 5, issue 2-3.

Schwartz, SH., Cieciuch, J., Vecchione, M., Davidov, E., Fischer, R., Beierlein, C., Ramos, A., Verkasalo, M., Lönnqvist, J.- E., Demirutku, K., DirilenGumus,O., \& Konty, M. (2012). Refining The Theory Of Basic Individual Values. Journal of Personality and Social Psychology, 103(4), $663-688$.

Zittoun, T and Gillespie, A. (2015). Internalization: How Culture Becomes Mind. Culture Psychology, 21 (4). pp. 477-491. ISSN 1354-067X. 